\title{
The Relation Between Prices and Employment: Two Views
}

M ONETARY and fiscal authorities are currently confronted with the task of simultaneously slowing price increases and maintaining employment growth. Policies directed toward the achievement of both objectives are affected by the policymakers' understanding of the underlying factors influencing prices and employment (or unemployment). Two principal views on this issue have emerged in the past decade. One stresses the short-run "trade-off" between prices and unemployment, and the other emphasizes the absence of a stable long-run relationship between varying rates of anticipated price changes and the level of unemployment. The short-run, for purposes of this analysis, is a period in which the relevant economic factors do not fully adjust to expectations, while the long-run is a period in which the values of actual and anticipated variables coincide.

This article discusses these two views of the relation between prices and employment without delving excessively into the theoretical complexities of the relation. For expositional purposes, the two views are discussed separately, because the literature tends to be divided into these two groups. The purpose of the article, however, is to demonstrate that the differences between the two views stem primarily from the emphasis on short-run vs. long-run considerations rather than from diametrically opposing theories or models. Whether the short run or the long run is emphasized has substantially different implications for stabilization policy. These different implications are discussed in the concluding section of the article.

\section{The Short-Run Trade-Off View}

High levels of unemployment in this country have generally been associated with slowly changing price levels, while low levels of unemployment have usually been accompanied by rapidly rising prices. These observed relationships have prompted attempts to explain price variations through changes in unemploy. ment relative to the labor force. The Trade-Off View does not focus on unemployment as a determinant of prices directly, however. It holds that unemployment and the rate of change of unemployment influence money wages, and wage changes, in turn, bring about changes in the level of prices.

A. W. Phillips' study of the relation between wages and unemployment in England is generally considered the point of departure for most recent investigations into the trade-off controversy. ${ }^{1}$ Phillips constructed a "trade-off curve" between the unemployment rate and wage changes, which indicated that wages in Great Britain rose rapidly when unemployment was declining and slowly when unemployment was rising. The "Phillips curve" was drawn to reflect a relationship between wages and unemployment, but other analysts have maintained that a similar relationship holds between prices and unemployment." They have assumed or observed that the factors which influence wages similarly influence other prices, or that wages are a principal independent determinant of prices.

Those analysts who follow Phillips in stressing a trade-off between wages or other prices and unemployment have found several factors besides employment pressures which apparently determine wage changes. Factors most often included in this group are profits, productivity, and the cost-of-living. Employment pressures, however, remain the primary explanatory variable.

\section{Factors Infuencing Wage-Price Changes}

The unemployment rate reflects the state of the demand for labor, a demand which is derived from the demand for goods and services. In a period of rising labor demand, employers attempt to attract workers from one another, thus bidding up wage rates. Additional labor may be obtained by attracting,

\footnotetext{
1A. W. Phillips, "The Relationship Between Unemployment and the Rate of Change of Money Wage Rates in the United Kingdom, 1861-1957," Economica, Vol XXV (November 1958), pp. 283-299.

2See, for example, George L. Perry, Unemployment, Money Wage Rates, and Inflation (Cambridge: The M.I.T. Press, 1966), p. 107. Perry states that "the factors affecting wage changes have been analyzed on the assumption that the wage relation is central to an understanding of the inflation problem."
} 
through higher pay, such "secondary" or "reserve" workers as housewives, stadents, retired persons, or those already holding one job. The ability of workers to obtain large wage gains may be increased in periods of rising demand for goods and services when employers are especially anxious to avoid strikes. Profits are usually higher and inventories are often at lower levels when demand is high; consequently, employers probably exhibit less resistance to wage demands at such times.

A state of falling demand for goods and services and labor is reflected in a higher unemployment rate. According to Phillips, ". . . it appears that workers are reluctant to offer their services at less than the prevailing rates when the demand for labour is low and unemployment is high so that wage rates fall only very slowly."3

Changes in both profits and consumer prices are positively associated with changes in wages in the Trade-Off View. Workers often use high earnings reports and cost-of-living advances to improve their bargaining position. Some labor groups have cost-ofliving escalator clauses written into their wage contracts.

No general agreement relating productivity and wage changes can be found among those who favor the Trade-Off View. Statistical studies have produced conflicting results.* Analysts have found insignificant, significantly positive, and significantly negative relationships between productivity and wage changes. Consequently, for purposes of analysis, productivity is generally assumed to increase at some constant rate. Analysts then can focus on the effects of changes in other variables, particularly unemployment, on wage rates.

Most observers who emphasize the Trade-Off View relate money (nominal) wage changes to the above explanatory variables through regression analysis. If all but one of the explanatory factors are held constant, a relationship between one variable - usually the unemployment rate - and wages can be depicted graphically. The resulting curve slopes downward from left to right, and is usually shaped similar to the rounded "L" determined by Phillips. (See Figures 1 and 2). The non-linear shape suggests the existence of a critical high-employment range. According to Levy,

3Phillips, p. 283.

${ }^{4}$ See Ronald G. Bodkin, The-Wage-Price-Productivity Nexus, (Philadelphia: University of Pernsylvania Press, 1966), pp. 143-151, for a discussion of such studies as well as Bodkin's own regression results.
"That price inflation, rather than reduced unemploy. ment, is the main result of any expansionary policy after the economy has reached a critical high employment range, is a basic inference from traditional economics which is rarely questioned."

The critical high-employment range may be defined as that range in which the number of employment vacancies are approximately equal to the number of workers seeking employment. ${ }^{.}$By this definition, excess demand in the labor market exists when the number of vacancies exceeds the number of job seekers, and there is an excess supply of labor when the number of workers seeking employment exceeds the number of vacancies. Excess demand causes wage rates to rise rapidly in the former case, and excess supply in the latter case tends to slow the rate of wage increase. Labor demand and supply factors may vary from sector to sector, but there is some evidence that a close tie exists between the “. . . aggregate unemployment rate and unemployment among various subgroups in the population."

\section{The Stability of the Phillips Curve}

An issue of particular importance to policymakers is the stability of the prices (wages)-employment relationship. Most Trade-Off View studies, by holding constant those factors other than unemployment which determine wages, do not stress fluctuations within a Phillips curve, shifts of the curve itself, or changes in the critical high-employment range. These studies, which rely heavily on regression analysis, often imply that the economy is operating on a single curve, and stabilization actions directed toward guiding the economy to some point off the curve may prove unsuccessful. Such studies, strictly interpreted, indicate that the Phillips curve is a stable relationship. ${ }^{8}$ This implication is refuted by Michael Levy, who found that "during the post-war years, the basic (Phillips curve) relationship for the U.S. economy between wage rate advances on the one hand, and

5Michael E. Levy, "Full Employment Without Inflation," The Conference Board Record, Vol. IV (November 1967), p. 36.

BEdmund S. Phelps points out that labor union behavior and the existence of "unemployables" may partially account for the fact that excess demand in the labor market seldom appears to exist, that is, "... vacancies almost never exceed unemployment." See "Money-Wage Dynamics and Labor-Market Equilibritum," The Journal of Political Economy, Vol. LXXVI (July/August 1968), p. 686.

TPerry, p. 25.

8Stability exists, technically, when the parameters computed for various time periods appear to be drawn from the same underlying population. 


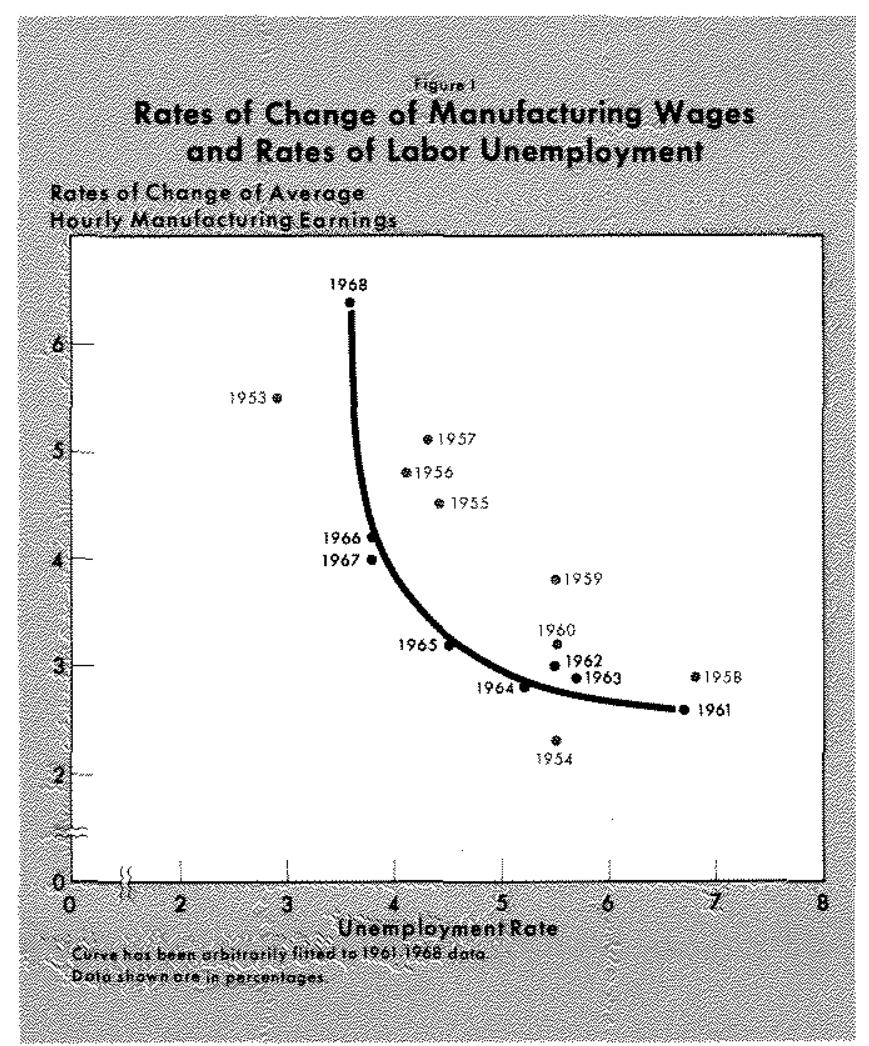

the unemployment rate, the corporate profit rate, and cost-of-living increases on the other, has been highly unstable." [Italics omitted]

Although the relationship may be technically unstable, a plotting of the wage and price changes and the unemployment rate reveals that Phillips' hypothesis - regarding the association of declining unemployment with rapidly rising wages (prices), and rising unemployment with slowly changing wages (prices) - has been generally observable over the past sixteen years. A simple correlation between two variables, as given here by a plotting of points on a twodimensional graph, does not demonstrate causality, however. The relationship between the rate of change of manufacturing wages and the unemployment rate for the 1953-1968 period is plotted in Figure 1. The curve, which is similar in shape to the curve determined by Phillips, has been arbitrarily drawn to fit the data from 1961 to 1968 , a period of uninterrupted economic expansion. ${ }^{10}$ The shape of the curve would be altered to some extent if fitted to the

9Levy, p. 37. Levy's conclusion is based on a statistical technique ("the Chow test") designed to test the degree of stability among relationships.

10The 1961 to 1968 curve for the United States mirrors more closely the relationship found by Phillips than do other possible subsets of the sixteen observations. Moreover, the fitting of the curve to the last eight years emphasizes the
1953-1960 period. For the sixteen-year period, the curve would be shifted slightly to the right.

Graphical trade-off analysis usually focuses on the wages-unemployment relationship, but it has also been extended to the prices-unemployment relationship as has been done in Figure 2. The overall fit for the sixteen-year period would not be as satisfactory as in the previous chart, but there is a close parallel for the past eight years. In some earlier years, sharp price increases occurred at varying rates of unemployment. Unemployment averaged slightly above 4 per cent of the labor force in the 1955 to 1957 period, more than 5 per cent from 1959 to 1960 , and a little less than 4 per cent in the 1965 to 1968 period. This evidence suggests that the critical high-employment range has varied, perhaps reflecting the changing nature of the labor force in particular and the economy in general.

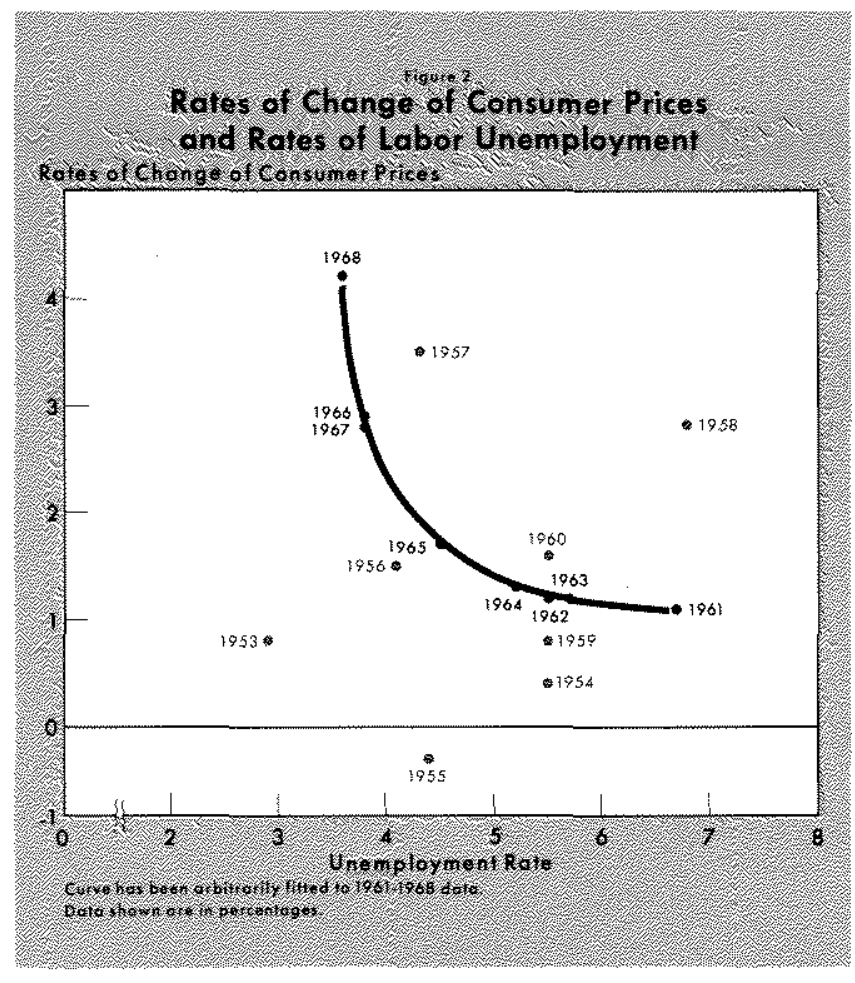

present position on the "low unemployment-rising wages" portion of the curve. Annual data were used in keeping with Phillips original work. The problems inherent in using annual data in the Phillips curve relationship are well known. "... we regard the construction of a plausible Phillips curve from annual data for a long period as a tour de force somewhat comparable to writing the Lord's Prayer on the head of a pin, rather than as a guide to policy. This is because it is highly probable that the relationship has changed during the period... and becanse of the large changes in some of the variables that take place during the course of a calendar year and are blurred in the annual data." Albert Rees and Mary T. Hamilton, "The WagePrice-Productivity Perplex," Joutnal of Political Economy, Vol. LXXV (February 1967), p. 70. 
Phillips curves derived from regression analysis are based on rather specific assumptions, and the shape can vary substantially when mincr modifications of the behavioral assumptions are made, as illustrated by the two following examples. A basic curve derived by George Perry relating consumer prices and unemployment was constructed from an equation in which prices were allowed to respond freely to market pressures. By assuming instead that half of the price increases were autonomous, Perry found that the curve, fairly steeply sloped in the first instance, became relatively flat. In fact, the slope of the curve was less than half of that calculated originally. ${ }^{11}$

Ronald Bodkin ${ }^{12}$ determined a near-horizontal linear relation between wages and unemployment. Rees and Hamilton, ${ }^{13}$ utilizing the same data and nearly the same assumptions as Bodkin, found a much steeper curve. Their results precipitated the remark:

Our final caution is that we have been astounded by how many very different Phillips curves can be constructed on reasonable assumptions from the same body of data. The nature of the relationship between wage changes and unemployment is highly sensitive to the exact choice of the other variables that enter the regression and to the forms of all the variables. For this reason, the authors of Phillips curves would do well to label them conspicuously "Unstable. Apply with extreme care."

This conclusion implies that the usefulness of such statements as ". . . 4 percent unemployment is con. sistent with a 2 percent rate of inflation if profit rates are at 11.6 per cent . . ."14 is limited by the validity of the assumptions which underlie the model.

\section{Characteristics of the Trade-Off View}

The chief characteristics of the Trade-Off View might be summarized as:

1) The relation between money wages and unemploycent is stressed, rather than the prices-unemployment relation.

2) Money wage changes are assumed to be a primary, if not the primary, determinant of changes

11Perry, p. 68.

${ }^{12}$ Bodkin, p. 279 .

13Rees and Hamilton, p. 70.

14Perry, pp. 108-109. in prices of final goods; consequently, changes in prices of final goods follow wage changes.

3) The relevant variables are specified in nominal rather than real (or price-deflated) terms.

4) The basic relationships are established by the use of regression analysis using observed data.

5) The relation between rates of wage or price changes and the unemployment rate may be represented by a line which curves downward on a graph from left to right.

6) The rationale behind movements along the Phillips curve, rather than shifts of the curve itself, is stressed. The policymakers attempt to attain the point on the curve which seems least undesirable.

7) The time units and period covered by the analysis are specified in terms of months, quarters, or years. Phrases such as "the length of time required for the factors to reach their long-run values" are not found in the Trade-Off View.

\section{The Long-Run Equilibrium View}

The Long-Run Equilibrium View considers the trade-offs between wages or prices and unemployment as transitory phenomena, and that no such trade-off exists after factors have completely adjusted to the trend of spending growth. In the short-run there can be a discrepancy between expectations and actual price or wage changes, but not in the long-run. After the discrepancies between expected and actual values have worked themselves out, the only relevant magnitudes are "real," or price-deflated ones.

To illustrate the view, consider the following hypothesized sequence of events in the upswing of a business cycle, beginning with an initial condition of significant unemployment. Monetary or fiscal actions may start an upturn of business activity. Spending occurs in anticipation of a continuation of the price levels which had prevailed in the downswing. Employers begin actively seeking workers to accommodate the rising demand, but wages increase only moderately since a large number of unemployed are seeking jobs. Output and employment rise more rapidly than wages or prices. The remainder of the scenario is outlined by Milton Friedman:

Because selling prices of products typically respond to an unanticipated rise in nominal demand faster than prices of factors of production, real wages received have gone down - though real wages anticipated by employees

Page 18 
went up, since employees implicitly evaluated the wages offered at the earlier price level. Indeed, the simultaneous fall ex post in real wages to employers and rise ex ante in real wages to employees is what enabled employment to increase. [The non-technical reader may wish to substitute "anticipated" for "ex ante" and "actual" for "ex post."] But the decline ex post in real wages will soon come to affect anticipations. Employees will start to reckon on rising prices of the things they buy and to demand higher nominal wages for the future. "Market" unemployment is below the "natural" level. There is an excess demand for labor so real wages will tend to rise toward their initial level. ${ }^{15}$

As real wages approach their original level, employers are no longer motivated to hire workers as rapidly or bid up wages so much as in the earlier portion of the upswing. Moreover, rising wages may encourage employers to utilize more labor-saving equipment and relatively fewer workers. As the growth of demand for labor slows, the unemployment rate declines to its "natural" level. Economic units come to anticipate the rate of inflation, and are no longer misled by increases in money income - the so-called "money illusion." The unexpected price increases which accompanied the original expansion of total demand and production caused a temporary reduction of unemployment below the long-run equilibrium level. Only accelerating inflation - a situation in which actual price rises continue to exceed anticipated rises - can keep the actual unemployment rate below the "natural" rate.

Inflation has not been allowed to rise uncontrolled for sustained periods in this country, so little empirical evidence can be amassed to support the contentions that no permanent trade-off exists. In other countries such as Brazil, however, it has been found that sustained inflation does not generate continuous employment gains; in fact, recessions and high unemployment rates have occurred as secular inflation continued. Unanticipated price increases have, in those countries as well as in the United States, generated increased

15Milton Friedman, "The Role of Monetary Policy," The American Economic Review, Vol, LVIII, (March 1968), p. 10 .

16Phelps, pp. 682-683, provides a comprehensive listing of several athors and their variations of the "anticipated inHation" thesis. Also, see: Charles C. Holt, "Improving the Labor Market Tradeoff Between Inflation and Unemploy. ment" (Working Paper P-69 1, The Urban Institute, Washington, D. C., February 20, 1969). temporary employment, just as unanticipated declines in the rate of price increase have caused temporary rises in unemployment. But if inflation is "fully and instantaneously discounted, the Phillips curve becomes a vertical line over the point of equilibrium unemployment.' This is the rate of unemployment where wage increases equal productivity gains plus changes in income shares. The unemployment-price stability trade-off is gone." 17 In other words, there is no particular rate of price change related to a particular rate of unemployment when the price changes are fully anticipated. Unemployment shifts to its equilibrium value and is consistent with any rate of change of prices. A low rate of unemployment can no longer be "traded-off" against rapidly rising prices, nor can a high unemployment rate be "traded-off" against slowly changing prices.

\section{Costs of Information}

A modified version of the Long-Run Equilibrium View is framed in terms of costs of obtaining information about job opportunities. When the demand for labor is low, the costs to a worker of discovering the state of labor demand are relatively high because employers are not actively seeking workers by publicizing extensive lists of vacancies. Employers are not as likely to absorb job training and transfer costs as they are when aggregate demand is rising. When labor demand rises and employers begin bidding up wage rates to attract additional labor, the costs of information, training and transferring are lowered to employees. The lower costs mean that employees will not have to search as long for acceptable employment, and the shorter the search time, the lower the rate of unemployment. Rising wages are accompanied by a declining unemployment rate. ${ }^{18}$

A reversal of stimulative policies will generate declining demand for labor. Some workers will accept smaller wage increases or reduced wages, but others will prefer to leave their jobs to seek employment at their former money wage rates. They expect prices

${ }^{17}$ Henry C. Wallich, "The American Council of Economic Advisers and the German Sachverstaendigenrat: A Study in the Economics of Advice," The Quarterly Joutnal of Economics, August 1968, pp. 356-357.

18The cost of information analysis is derived from studies by George J. Stigler, "Information in the Labor Market," Journal of Political Economy, Vol. LXX (Supplement: October 1962), pp. 94-105; and Armen A. Alchian and William R. Allen, University Economics, 2nd ed, Chapter 25 (Belmont, Calif.: Wadsworth Publishing Company, Inc. 1967). Also see Armen A. Alchian, "Information Costs, Pricing, and Resource Unemployment" in a forthcoming issue of the Western Economic Journal. 
and wages will remain at their earlier, higher levels. Prices and output will have fallen, however, and the high real wage rate will have stimulated employers to lower the quantity of labor demanded, thereby raising search costs to those workers who leave their jobs to seek employment elsewhere. ${ }^{19}$ Higher search costs and lower money wage rates will be accompanied by rising unemployment. When workers realize that demand and price increases have slowed, they will be willing to accept the lower money wage rates and unemployment will stabilize at the "natural" level. For the stabilization to occur, however, no money illusion can exist. Anticipated wage (or price) changes must equal actual wage (or price) changes.

The costs-of-information approach combines the two factors determining the equilibrium rate of unemployment - the structure of real wage rates as determined by labor demand and supply, and "imperfections" within the labor market. ${ }^{20}$ Bottlenecks, labor and product market monopolies, positive costs of information, training and transfers create "imperfections" in the labor market. In other words, all markets are not cleared instantaneously and without cost. At any point in time the degree of the so-called "imperfection" within the labor market will vary, depending on transactions and information costs; correspondingly, the "natural" rate of unemployment will vary.

Enactment of policies oriented toward eliminating or reducing market imperfections (adjustment costs) will cause the short-run Phillips curve to shift to the left and down. Policies which increase these costs move the short-run Phillips curve upward and to the right. Different forces are at work at different times, causing the curve to shift frequently. Expectations

\footnotetext{
19The Committee for Economic Development points out that "slow adjustment to unexpected price increases may increase employment as prices accelerate, but this slow adjustment may also cause an increase in unemployment as the rate of price inflation slows. The temporary trade-off is a double-edged sword." Fiscal and Monetary Policies for Steady Economic Growth, a statement on National Policy by the Research and Policy Committee of the Committee for Economic Development, Jantary 1969 , p. 40.

20The Equilibrium View maintains no monopoly over discussions of the relevance of labor market structure; indeed, Lipsey's rigorous reformulation of Phillips' original view was predicated to a large extent on the importance of unemployment among different sectors of the economy. See $R$. G. Lipsey, "The Relation between Unemployment and the Rate of Change of Money Wage Rates in the United Kingdom, 1862-1957: A Further Analysis," Economica, Vol. XXVII (February 1960), pp, 1-31. On the whole, however, it seems that the Equilibrium Vlew, which stresses the reasons for the changing nature of the shor:run Phillips curves - varying expectations and cost-of-infor mation - is the view in which structural considerations should be discussed.
}

of higher prices will cause the curve to shift upward, and expectations of lower prices move the curve in the opposite direction. The optimal stabilization policies, therefore, would be those which would reduce market adjustment costs and expectations of higher prices. Enactment of such policies would at first inove the short-run Phillips curve to the left and downward, and in time, as expectations are fully realized, cause the curve to become a vertical line over the "natural" rate of unemployment.

A hypothetical, long-run relationship between prices and unemployment is presented in Figure 3. Point D represents the "natural," or equilibrium rate of unemployment before market imperfections or adjustment costs are reduced. Curve A represents one of many possible short-run Phillips curves that exist before price changes are fully anticipated. After the rate of inflation becomes fully discounted, the unemployment rate will shift from some point beneath curve $A$ to point $D$, regardless of whether prices are rising at some slow rate, $X$, or a rapid rate, $Z$. The shift may oocur along any of an infinite number of Phillips curves. The vertical line above point $\mathrm{D}$ indicates that no economic units - workers or employers, sellers or

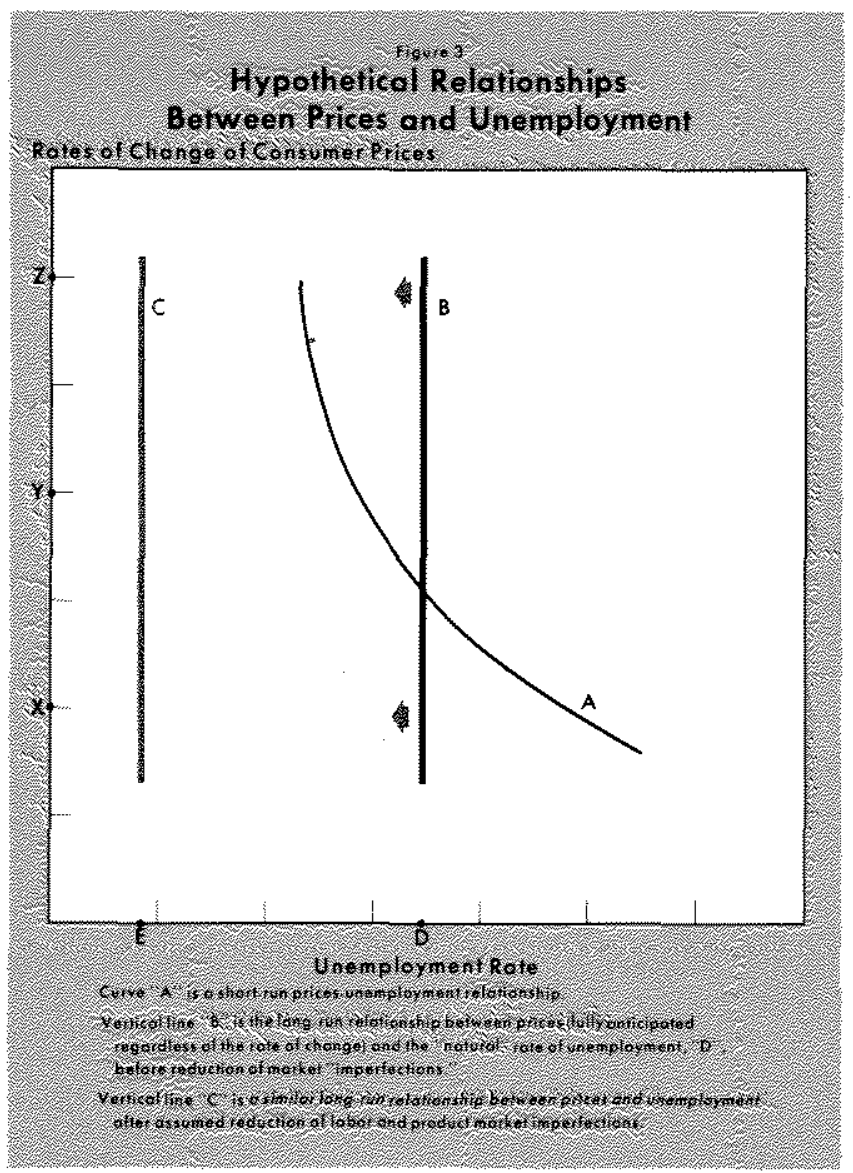


consumers, borrowers or lenders - are surprised by price changes. If programs to reduce labor and product market imperfections are implemented, vertical line $B$ will shit, after a transitory period, to the left. Vertical line $C$ represents the new long-run relationship between prices and employment above point E.

\section{Characteristics of the Long-Run}

\section{Equilibritu View}

The principal characteristics of the Long-Run Equilibrium View might be summarized as:

1) The relationship between all prices and unemployment is emphasized, rather than the wagesunemployment relation.

2) Changes in selling prices usually precede changes in the prices of productive agents.

3) The relevant economic factors are specified in real rather than nominal terms.

4) Because of the lack of data on accelerating inflations, expectations of price changes, and the "natural" rate of unemployment, the analysis is generally accomplished through abstract reasoning rather than empirical testing.

5) The relation between the long-run rate of price or wage changes and the unemployment rate is a vertical line over the equilibrium rate of unemployment.

6) The long-rum relationship and reasons for observed shifts of the Phillips curve are stressed. The authorities do not have to choose as a target some fixed relationship between prices and unemployment on a Phillips curve, but can attempt to move the economy off a short-run curve. In the long-run, they can seek any trend in prices desired without a sacrifice in terms of foregone employment or production.

7) The time period of the analysis is not specified. In the long-run, the actual values of the relevant economic variables equal the expected values, while in the short-run, they do not.

\section{Policy Implications of the Two Views}

Unemployment declined from 5.2 per cent of the labor force in 1964 to 3.5 per cent in 1968. The annual rate of increase in consumer prices rose from 1.3 per cent to 4.2 per cent for corresponding years. These data indicate, according to the Trade-Off View, that stabilization authorities must decide to accept either high rates of price increases in order to maintain low unemployment rates, or adopt deflationary measures and accept relatively high levels of unemployment. Only significant reductions of imperfections within the product and labor markets could prevent employm ment declines in the face of deflationary policies.

Proponents of the Long-Run Equilibrium View point out that even in the absence of structural improvements, monetary and fiscal policies need not be limited by a short-run trademoff between prices and employment. Continuation of expansionary developments will generate either (1) a high, steady rate of inflation which will eventually become fully anticipated and confer no net additional employment benefits (unemployment will gradually return to its "natural" rate), or (2) an accelerating rate of inflation which will permit unemployment to remain below the "natural" rate. Neither expansionary policy alternative appears economically or politically desirable. Deflationary actions would produce increased unemployment (as expectations of price changes are slowly revised) but only temporarily, according to the Equilibrium View. As soon as a new price trend becomes stabilized and fully anticipated, nominal and real wages will coincide, and unemployment will fall to its "natural" rate. An inflationary policy is neither a necessary nor a sufficient condition for the attain ment of high levels of employment. Since price expectations seem to change only slowly, actions to reduce the rate of inflation should probably be applied gradually to minimize the transition cost in terms of reduced output and increased unemployment.

Both views recognize the merits of structural measures in complementing monetary and fiscal actions. Policies which reduce the costs of obtaining employment information, improve labor mobility and skills, and eliminate product and labor market monopolies will lower the optimal level of unemployment. Adoption of such policies would improve the short-run dilemma faced by monetary and fiscal authorities and enable them to shift their Iong-run unemployment target to a lower level.

ROGER W. SPENCER

This article is available as Reprint No. 36. 